\title{
МОВНІ ЗАПОЗИЧЕННЯ НА ІСТОРИКО-ФІЛОЛОГІЧНОМУ ТЛІ
}

Статтю присвячено взаємодії української мови з англійською, франиузькою й німецькою мовами в процесі їх контактування. Ці мови обрано для дослідження через їхню поширеність і вплив на інші мови світу. Незважаючи на відмінності їхніх мовних картин світу, загальним залишається аспект логіко-психологічного мислення людини. У статті проаналізовано основні закономірності еволюиії мови, установлено шляхи, засоби й причини запозичування, визначено функиіі запозичених слів та розглянуто історичні процеси, пов'язані з ними.

Ключові слова: запозичення, тексико-семантична група, асиміляція, мовна картина світу, еволюція, концептуальна картина світу.

\section{Simonok V. Language Borrowings on the Historical and Philological} Background. The actuality of this article is predefined by the fact that borrowings were and remain one of the important ways of the extending the Ukrainian language vocabulary, and that is why need the detailed study of their volume and different semantic processes of borrowing, adaptation, and development of foreign words, and their place in the Ukrainian lexical system. Borrowing is one of the forms of mastering of the experience of a nation with which the other nation is in contact.

The purpose of the article is to study the history of inclusion into the Ukrainian language of the certain groups of the adopted vocabulary as a result of the socialeconomic and political contacts of Ukraine with other states at various historical stages. The question of contacts is complex through the variety and multidimensionality of such ethnic contacts of Ukrainians and their ancestors with different people in different directions - east, west, south, and north. Some borrowings got in Ukrainian directly, the others - through the mediation of other languages. The confirmation of this conception can be found in the works by B. Rassel, R.O. Yakobson, G.V. Kolshanskyi, etc.

The task of the article includes the research of the history of forming the system of borrowings from the Romance and Germanic languages, the description of the principles of word borrowings into Ukrainian, and ways of their including and assimilation in the conceptual and linguistic picture of the world. The borrowed words are divided into the old ones that entered as early as the pre-literate period and those ones which entered at different historical stages of contacts of Ukrainians with other people.

Consequently, the adopted vocabulary, co-operating with the basically Ukrainian names, makes a considerable layer of words characterized with wide application by 
language speakers and high dynamics. With the international connections strengthening, a chronologic sequence disappears and a certain correlation of ethnic and social aspects appears: names related to fashion and daily routine are adopted from French; lexical units connected with handicraft and military businesses - from German; economy, engineering and sports related borrowings are from English. This process gradually accelerated with the development of society.

Key words: borrowings, lexical and semantic group, assimilation, linguistic picture of the world, evolution, conceptual picture of the world.

\section{Вступ}

У сучасній україністиці питання про запозичення й асиміляцію лексичних одиниць розглянуто в численних дослідженнях (В. В. Жайворонок, М. А. Жовтобрюх, Ю. О. Жлуктенко, С. В. Семчинський, Л. О. Симоненко та ін.), проте більшість із них має переважно класифікаційний характер, не стосується глибинних семантичних процесів.

Актуальність цієї статті зумовлена, по-перше, тим, що запозичення були й залишаються важливим, а в деяких лексико-семантичних групах (ЛСГ) одним з головних шляхів поповнення словникового складу української мови, а тому є потреба докладного вивчення семантичних процесів запозичування, адаптації й розвитку іншомовних слів, їхнього місця в лексичній системі української мови та мовній картині світу. По-друге, не зменшується увага сучасної лінгвістики до питання мовних контактів, до запозичень як засобу номінації.

Мета статті - дослідити історію становлення системи запозичень з романських і германських мов, схарактеризувати закономірності запозичування слів в українську мову, що $є$ однією з форм залучення досвіду народів, з якими перебували й перебувають у контакті українці, у їхню концептуальну (ККС) й мовну (МКС) картини світу. Її завдання: установити шляхи й причини запозичування; визначити функції запозичених слів; розглянути історичні процеси, пов'язані з ними. Аналіз використаної в роботі концепції висвітлено в працях Б. Рассела (Russel, 1950: 2-14), Р. О. Якобсона (Якобсон, 1985: 232), Г. В. Колшанського (Колшанский, 1984: 175) та ін. У процесі розвитку мови виникає невідповідність між концептуальною й мовною картинами світу, що можна пояснити впливом матеріальних і соціальних умов існування носіїв мови та національною своєрідністю бачення світу. Таку невідповідність задовольняють, з одного боку, змінами в мові внаслідок внутрішніх процесів, а з другого - запозичуванням. 


\section{Методи та методики дослідження}

Під час аналізу досліджуваного матеріалу використано метод компонентного аналізу для дослідження семантичної структури запозичених лексичних одиниць; прийомів описового методу - спостереження, систематизації й узагальнення; дескриптивний метод у процесі класифікації запозичень з англійської, німецької й французької мов у співвідношенні з українською МКС.

\section{Результати та дискусії}

Одним з аспектів дослідження запозиченої лексики в українській мові $€$ соціолінгвальний, що полягає у висвітленні історії входження в мову певних груп запозиченої лексики внаслідок суспільно-економічних і політичних контактів України з різними народами на різних історичних етапах.

Щодо тривалості функціювання в українській мові запозичені слова поділяють на давні, що були запозичені ще в дописемний період, ті, що входили на різних історичних етапах контактування народів у писемний період розвитку української мови, та сучасні. До давніх належать окремі германізми, успадковані від варягів (вал, гай, кліть, меч, шолом) (Шахматов, 1941: 87) та вікінгів (крюк, лар, пуд) (Преображенский, 1910: 78). Наслідком торговельних контактів 3 німецькими князівствами в XIII-XIV ст. $€$ певна кількість запозичень (варт, крам, кошт, ярмарок). 3 поширенням Магдебурзького права в XIV ст. з німецької до складу української мови входить окрема адміністративно-правова лексика: бургомістр, квит, рада, тюрма. Протягом XVI-XVII ст. з німецької запозичено будівельну лексику (кахлі, крейда, брама, паркан) та військову термінологію (абшит, брандмейстер, капрал).

У XVI-XVII ст. в українську мову починають проникати запозичені слова з французької мови. Це зумовлено, по-перше, впливом польського двору, що мав зв’язки з Францією, а по-друге - виправами козацького війська в європейських країнах, звідки воно й принесло запозичену військову лексику (алебарда, атака, бомбарда, пістоль) та дипломатичну термінологію (аудієнція, кондиція, сатисфакція). У XVIII ст. французький вплив серед козацької верхівки виявився в певних змінах у побуті, традиціях. Поряд з українськими національними назвами страв (борщ, вареники, галушки) з'являються нові 
(бульйон, десерт, шоколад) тощо. Козацька старшина вважає престижним мати в побуті такі меблі, як канапа, комод, фотеля й одягатися в камзол, сюртук, фрак.

Обмежена кількість слів англійського походження того часу належить здебільшого до торговельної лексики й одиниць виміру, наприклад: гінея, дюйм, миля, чек, ярд, що в українській мові майже не вживалися.

Одним із шляхів входження лексичних запозичень в українську мову XVIII ст. була література. Запозичення проникали також через мову привілейованих соціальних груп, що перебували на службі в закордонних місіях, при дворах і посольствах, та діячів культури, які навчалися за кордоном.

Протягом XIX ст. з розвитком науки й промисловості в певних галузях передують англомовні країни, через що українська мова й збагатилася англіцизмами гравітація, електроліз, інерція. Французькі запозичення були представлені назвами міжнародних і політичних документів: нота, пакт, ратибікація; предметів побуту: бра, гарнітур, канделябр, німецькі - технічними назвами: зумер, керн, мульда, орт.

У XX ст. перевага повністю належить англійським запозиченням у галузях ринкової економіки: консалтинг, транш, тренд; високих технологій: когерер, фединг; спорту: скайбайкеринг, сноубординг; масмедіа: niap, xim, шоу-бізнес та ін. Німецькі запозичення представлені металургійною термінологією: веркблей кобальт, роштейн; військовими термінами: абвер, аусвайс, гестапо та назвами тканин: варсолан, дедерон, перлон і т. ін. Французькі запозичення пов'язані з високою модою (Haute couture): дефбіле, модель, прет-а-порте.

Виділяють три етапи рецептивної асиміляції запозичень. Перший називають використанням або проникненням. На цьому етапі слово з'являється епізодично, зберігає іншомовне написання й ще належить до мовної картини світу мови-джерела. На другому етапі запозичене слово використовують набагато частіше, хоча й відчувається його чужорідність. На третьому етапі запозичене слово вже не сприймається як іноземне й повністю підпорядковується законам української мови.

На запозичування, як і на розвиток мови взагалі, впливають зовнішні та внутрішні чинники. Зовнішні відбивають зв'язки мови з різними аспектами людського існування й історії суспільства, через які відбувається зв’язок історії мови з історією народу. 
До внутрішніх причин запозичування відносять: 1) потребу уточнення або деталізації відповідних значень наявного слова, наприклад, запозичені назви: аутригер, бриг, вельбот розрізнюють назви кораблів за конструкцією та функціями; 2) прагнення до економності мовної системи, наприклад, (укр.) кінні змагання для трьох- та чотирьохрічних верхових рисистих коней - (англ, derby) дербі.

Причиною запозичування може бути престиж тієї чи тієї мови: наприклад, вплив французької мови, коли Франція стала гегемоном у культурному житті та філософії в XVII-XVIII ст., у наші дні перевагу має англійська мова.

До причин запозичування можна також віднести номінативні потреби. У кожного народу існує своя картина світу, що значною мірою виявляється в предметній сфері. Слова на позначення конкретних предметів запозичуються не поодинокими лексемами, а цілими лексико-семантичними групами, що відображають відповідний фрагмент мовної картини світу.

Мовні контакти як визначальні чинники в процесі запозичування можуть бути безпосередніми або опосередкованими. Перший тип контактів відбувається в політичних, економічних і культурних відносинах між народами, що живуть поруч. Значну роль у поширенні запозичених слів в українській мові відіграють білінгви, що володіють українською та однією з інших мов. При цьому для засвоєння іншомовних слів достатньо двомовності не всього населення, а тільки його частини.

Запозичені слова в українській мові виконують різні функції: 1) номінативну, що задовольняє потребу мови в засобах номінації; 2) аксіологічну, що збагачує мову оцінними й експресивними засобами; 3) стильову, що полягає в диференціації власне українських і запозичених слів залежно від типу мовлення; 4) семантичної диференціації або ідентифікації понять українського й запозиченого слів; 5) термінотворення; 6) інтернаціоналізації певних шарів лексики та глобалізації окремих складників МКС.

Окрім зазначених основних, Л.М. Пелепейченко (Пелепейченко, 1994: 40-50) вирізняє перехідні специфічні функції: номінативно-екзотичну - називання реалій, не властивих питомо українській МКС. Це, зокрема, назви екзотичних істот (анаконда, тама, нанду), рослин (банан, гікорі, батат), споруд (бунгало, вігвам). Для таких слів 
англійська та іспанська мови є не джерелом, а посередником, а джерелом виступають маловідомі мови інших народів. Наприклад, анаконда (індіан.) - змія родини удавових, бamam (iсп. batata, з мови таїно) - солодка картопля, бунгало (англ, bungalow, з інд. бангло) - легка позаміська будівля з верандами, вігвам (англ, з алгонкінської) - житло, гікорі (англ, hickory з індіан.) - горіх, нанду (ісп. fiandi з індіан. мов) - американський страус, пума (ісп. 3 мови кечуа) - ссавець родини котячих.

У номінативній функції виділяють номінативно-уточнювальну, притаманну запозиченням, що мають відповідники в українській мові, але доповнюються семами 3 лінгвокраєзнавчим компонентом (країна, релігія): иерква - православний храм, кірха - лютеранський храм; костел - католицький храм, мечеть - мусульманський храм. Ця функція пов'язана з тим, що відповідні концепти відомі, але не властиві українському етносові, бо виражають явища й поняття інших народів.

Досліджений матеріал дає змогу виявити, що запозичення з англійської, французької та німецької мов в українську не є поодинокими, а становлять семантичні блоки, співвідносні з певним простором у концептуальній і мовній картинах світу. Ці блоки вступають у системні зв'язки й з лексикою української мови, і із запозиченою.

I. Суспільно-політична лексика. Кожна епоха має свою суспільнополітичну термінологію, вживану на позначення ладу, класового поділу, суспільно-правових взаємин і т. ін. Ця лексика перебудовується разом зі зміною певної суспільно-історичної формації, тобто великою мірою піддається регулювальному впливу суспільства.

За семантикою іншомовні слова, що належать до суспільно-політичної лексики, можна поділити на такі групи:

1) політологічна: а) назви явищ суспільно-політичного (брифінг, рейтинг, саміт) і соціального життя (драг-дилер, пресинг, прес-реліз, диктат, нічиеанство);

2) адміністративна: губернатор, конгрес, крайстаг, мерія, итат;

3) правова термінологія: алібі, еміграція, кіднепінг, рекет, тероризм, uтраф.

До суспільно-політичної лексики належать слова, що сьогодні входять до активного словника української мови у зв'язку з суспільно-політичними змінами в суспільстві. Серед них: бандитизм, корупизя, обб-рекорд, пабліситі, прес-реліз, фелоні. 
II. Соціально-економічна лексика. Основу цієї лексичної групи становлять слова, пов'язані з фінансово-економічною й торговельною діяльністю суспільства. У зв'язку із цим активізувалося функціювання ряду лексем, що їх раніше вживали тільки для позначення явищ капіталістичного світу: ажіотаж, вексель, дефічит, інфляція; відбулися зміни в семантичній структурі окремих слів. Наприклад, слово aуmсайдер у спортивній термінології позначає 'спортсмен або команда, що посідають останні місця в змаганнях’. У межах фінансово-економічної термінології це слово позначає 'підприємство, що не входить до монополістичних об’єднань і веде з ними конкурентну боротьбу’

До аналізованої групи слів належать: 1) назви цінних паперів: банкнота, валюта, вексель, облігація; 2) платіжні документи: чек, прейскурант; 3) назви грошей: долар, евро, фунт (стерлінгів), сантим, марка, шилінг; 4) операції купівлі-продажу: аванс, аукціон, ексnорm, імпорт; 5) назви грошового стягнення або заохочення: грант, приз, итраф і т. ін.

Німецька мова першою виробила досконалу економічну термінологію й у XIV-XV ст. стала для української мови джерелом прямого запозичування слів: гандель, мито, пломба, ринок, ярмарок.

Наприкінці XX ст. в українській мові актуалізувалася велика кількість слів англомовного походження, пов'язаних з інвестиційною діяльністю та біржовими операціями: бредбериз, інфляиійний хедж консалтинг, обшор, транш, тренд.

III. Військова лексика. Група слів на позначення військової лексики класифікується за назвами: 1) збройних сил: армія, бундесвер, вермахт, рейхсвер; 2) військових з'єднань, родів військ, підрозділів: абвер, бригада, дивізія, гарнізон, гвардія, рота; 3) видів зброї й боєприпасів: бомба, динаміт, гаубиия, карабін, имайсер і т. ін.

Формування досліджуваної групи починається з XVI-XVII ст. через козаків, що перебували на службі в Німеччині та Франції. У цю добу до складу лексики української мови потрапила велика кількість німецьких та французьких запозичень: армія, блокгауз, варта, гетьман, куля, спис, флінта, цейхгауз.

У роки Другої світової війни ввійшли в обіг німецькі запозичення абвер, блічкриг, бункер вермахт, гестапо, фаустпатрон, шмайсер, французькі запозичення колабораціоніст, макі, нонкомбатант, франтирер та англійська назва джи-ай. Скороченням джи-ай 
користувалися лише інтенданти американської армії для позначення таких назв, як «м'ясні консерви», що згодом перетворилося на «гарматне м'ясо». На український грунт слово потрапило в значенні 'солдат армії США' як і назва янкі.

IV. Виробничо-технічна лексика. У системі запозиченої лексики виділяються такі групи слів: 1) назви пристроїв і механізмів, інструментів: бампер, дисплей, домкрат, лазер, міксер, мубта, пульт; 2) номінації промислових машин та засобів пересування: бульдозер, екскаватор, тролейбус, фунікулер; 3) назви технологічних процесів: бесемерівський (процес), фільтрація, шлібування; 4) назви друкарського виробництва: кегель, кліше, крокі, прес; 5) металургійна термінологія: блюм, сорбіт, бронза, кобальт, кокс.

Більша частина аналізованої лексики має вузькотермінологічне значення, відоме лише фахівцям: бремсберг - пристрій для спускання вантажів; бугель - металеве кільце. Але серед цієї лексики є слова, що знайшли широке використання в мові, напр.: домкрат, дрель, кабель, фен, центрифуга, шнур, штепсель і т. ін. У наші дні в мові активно функціюють слова, запозичені з англійської мови: дисплей, курсор, пейджер, принтер, сканер, телефакс, байл та ін.

V. Лексика будівництва та архітектури. Одна з найдавніших груп запозиченої лексики в українській мові пов'язана з будівництвом, спорудженням житла, інтер'єром. До XIV-XV ст. належать запозичені 3 німецької мови назви знарядь, інструментів тощо. Пізніше, з розвитком будівельної техніки й контактів з майстрами, що походили з інших країн, в українську мову входить іншомовна лексика з французької, протягом XX ст. - переважно з англійської.

Лексика будівництва та архітектури можна розподілити на кілька груп: а) назви споруд і їх устаткування: бунгало, котедж, мансарда, шато, флігель; б) деталей архітектури: вітраж, зокаль, карниз, фриз,

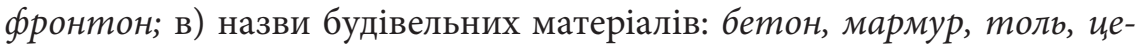
мент, шифер; г) інженерні споруди та ландшафтна архітектура: авеню, бульвар, віадук, газон, еспланада, естакада, тераса; г) предмети побуту: багет, бра, жалюзі, плабон, торшер, лампа, шаба; д) назви інструментів: кайло, лобзик, рубанок; е) назви професій: дизайнер, муляр, тесляр.

У широких кіл населення характерними назвами інтер'єру були слова: покута, закуток, піч, комин, груба. У XVII ст. було запозичено 
з німецької слово груба в значенні 'піч, призначена для опалення житлових кімнат'.

Слова групи «Будівництво та архітектура» можна розподілити на 2 підгрупи: загальновживану - клуб, галерея, колона, павільйон, паркет, тамбур, тераса тощо й спеціальну, термінологічну - дейка, брекватер, аркбутан, дольмен, канелюр, клуатр, фахверк, тобто лексику, відому лише будівельникам-фахівцям.

VI. Флоро- та фауноназви. Назви рослинного світу в українській мові належать до найдавніших. Прикладом питомо українських назв рослинного світу можуть бути кущ, береза, сосна, ялина, осика, клен та багато інших.

3 розширенням обріїв реального світу в коло уявлень слов'ян взагалі й українців зокрема входять назви численних рослин, що існують далеко за межами України й суміжних територій. Ці рослини потрапляли в Україну для поповнення дендраріїв, ботанічних садів, паркових зон, а також приватних колекцій аматорів-садівників. Переважно це екзотичні назви, що увійшли в українську мову за рахунок поширення ККС. Деякі з них притаманні романо-германським мовам: айстра, артишок, барвінок, бульденеж, гіацинт, каштан, квасоля, кмин.

Деякі назви перебувають на периферії української МКС, напр.: акажу, дюрабль, квебрахо, пачулі, салеп. Ціла низка рослин має в українській мові подвійну назву: мангольд - буряк, рокамболь - часникова цибуля, тагетас - чорнобривці.

В українській мові існує й значна кількість запозичених слів на позначення фауни. Не всі вони є екзотизмами для української МКС через часте їх уживання: антилопа, какаду, поні. В українську МКС потрапила значна кількість назв порід собак. Зокрема, з німецької мови увійшли такі назви, як доберман, кури- хар, мопс, пудель, шпич тощо. Французька мова обмежено представлена в цих назвах: бреар, бордоський дог, папільйон, сенбернар. 3 англійської мови в українську увійшла значна кількість назв, зокрема бульдог, бладхаунд, випет, голденретривер, дог, мастиф, ньюфаунленд, пінчер.

Екзотичними для нашої зони є окремі назви тварин (агуmi, армадили, беркщир, галаго, зебу) та риб (арапайма, мерлан, тюрбо). Добре відомі носіям української мови запозичені назви ракоподібних: краб, креветка, пангуст, омар як назви делікатесів. До 
вузькотермінологічної лексики належать слова: кошеніль - промислова назва кількох видів комах, міноги - безщелепні хребетні тварини. Обмеженому колу фахівців відомі слова блювал, нарвал, сейвал як назви китів.

VII. Побутова лексика охоплює такі назви: 1) предметів хатнього вжитку: абажур, валіза, келих, плед, сервіз; 2) страв: бекон, бісквіт, бібштекс, бутерброд, гамбургер; 3) напоїв: бренді, вермут, віскі, коктейль, кобе, пепсі, шампанське, шнапс; 4) закладів побутового обслуговування: бар, бістро, готель, кафе, паб, перукарня, трактир; 5) предметів одягу; його деталей, фасонів: бриджі, гольф, джинси, жакет, комбінезон, краватка, уніборма; 6) головних уборів: бейсболка, кепі, панама, иляпа; 7) предметів розкоші: бурштин, діамант, кабошон, парангон турмалін; 8) звичаїв, етикету, церемоній: бал, брудершафб, візит, ланч, раут. Верхи суспільства стежили за французькою модою й наслідували іï.

У різні часи залежно від вектора контактів, а також світових тенденцій у розвитку певної сфери життя змінюється й вектор запозичень; якщо протягом XVI-XIX ст. запозичення в побутовій сфері йшли переважно з французької, то у XX ст. помітно посилюється в цій царині вплив мови англійської, особливо в ії американському варіанті. Це й назви закладів харчування, де можна швидко поїсти: снекбар, квікбуд (швидка іжа); назви страв: бігмак, гамбургер, чизбургер, чикенбургер; назви напоїв: пепсі, кока-кола, спрайт, фбанта; назви одягу, взуття: джинси, жакет, пуловер, кепі, кросівки, бутси та ін.

\section{Висновки}

Отже, запозичена лексика, взаємодіючи з власне українськими назвами, становить значний шар слів, що характеризується широким ужитком у носіїв мови й значною динамічністю. Відносна хронологічна послідовність зумовлена поступовим розширенням зв'язків України 3 тими чи тими народами. 3 посиленням міжнародних зв'язків, особливо з їх глобалізацією, хронологічна послідовність зникає й відбувається інтернаціоналізація певної частини лексичного складу мов.

\section{ЛІТЕРАТУРА}

1. Колшанский Г. В. Коммуникативна функция и структура языка. Москва: Наука, 1984. 310 с. 2. Пелепейченко Л. Н. Переходные тип значений слов (на материале русского языка). Харьков: ХГПУ, 1994. 120 с. 3. Преображенский А. Г. 
Этимологический словарь русского языка: в 2 т. Москва: Тип. Г. Лиснера, Д. Собко, 1910. Вып. 2. С. 57-136. 4. Шахматов А. А. Синтаксис русского языка. 2-е изд. Ленинград: Учпедгиз, 1941. 620 с. 5. Якобсон Р. Избранные работы. Москва: Прогресс, 1985. 455 c. 6. Russel B. Logical positivism. Revue Internationale de philosophie. 1950. V. 4. N. 18. P. 2-14.

\section{REFERENCES}

1. Kolshanskij, G. V. (1984). Kommunikativna funkciya i struktura yazyka [Communicative function and structure of the language]. Moskva: Nauka [in Russian]. 2. Pelepejchenko, L. N. (1994). Perexodnye tip znachenij slov (na materiale russkogo yazyka) [Transitive type of meaning of words (on the material of the Russian language)]. Xar'kov: XGPU [in Russian]. 3. Preobrazhenskij, A. G. (1910). E'timologicheskij slovar' russkogo yazyka [Etymological dictionary of the Russian language], (Vyp. 2), (pp. 57-136). Moskva: Tip. G. Lisnera, D. Sobko [in Russian]. 4. Shaxmatov, A. A. (1941). Sintaksis russkogo yazyka [Russian syntax] (2nd ed., rev.). Leningrad: Uchpedgiz [in Russian]. 5. Yakobson, P. (1985). Izbrannye raboty [Featured Works]. Moskva: Progress [in Russian]. 6. Russel B. (1950). Logical positivism. Revue Internationale de philosophie, 4 (18), 2-14 [in English].

Сімонок Валентина Петрівна - доктор філологічних наук, професор, завідувач кафедри іноземних мов № 1, Національний юридичний університет імені Ярослава Мудрого; вул. Пушкінська, 77, м. Харків, 61024, Україна.

Tel.: $+38-050-918-11-81$

E-mail: kafedra.foreign1@gmail.com

http://orcid.org/0000-0003-3664-9218

Simonok Valentina - Doctor of Philology, Professor, Head of Foreign Languages Departement № 1, Yaroslav Mudriy National Law University; Pushkinska Str. 77, Kharkiv, 61024, Ukraine. 